Article

\title{
Characterization of Volatile Organic Compound (VOC) Emissions from Swine Manure Biogas Digestate Storage
}

\author{
Yu Zhang ${ }^{1,2}$, Zhiping Zhu ${ }^{1,2}$, Yunhao Zheng 1,2®), Yongxing Chen ${ }^{1,2}$, Fubin Yin ${ }^{1,2}$, \\ Wanqin Zhang ${ }^{1,2}$, Hongmin Dong ${ }^{1,2, *}$ and Hongwei Xin ${ }^{3}$ \\ 1 Institute of Environment and Sustainable Development in Agriculture, Chinese Academy of Agricultural \\ Sciences, Beijing 100081, China \\ 2 Key Laboratory of Energy Conservation and Waste Utilization in Agriculture e, Ministry of Agriculture, \\ Beijing 100081, China \\ 3 The University of Tennessee Institute of Agriculture, The University of Tennessee, \\ Knoxville, TN 37996-4506, USA \\ * Correspondence: donghongmin@caas.cn; Tel.: +86-10-8210-9979
}

Received: 13 June 2019; Accepted: 13 July 2019; Published: 18 July 2019

\begin{abstract}
Livestock manure is one of the major sources of volatile organic compound (VOC) emissions; however, characteristics of VOCs emitted from biogas digestate (BD) storage, which is a common manure practice, remain unclear. The objective of this study was to characterize VOC emissions during BD storage through the dynamic emission vessel method, to identify the VOC emissions that have potential odor and/or toxic effects. The results revealed the detection of 49 VOCs with seven classes, whose total concentration varied from 171.35 to $523.71 \mu \mathrm{g} \mathrm{m}^{-3}$. The key classes of the 49 VOCs included Oxygenated VOCs (OVOCs), olefins and halogenated hydrocarbons. The top four compositions, accounting for $74.38 \%$ of total VOCs (TVOCs), included ethanol, propylene, acetone and 2-butanone. The top four odorous VOCs, accounting for only $5.15 \%$ of the TVOCs, were toluene, carbon disulfide, ethyl acetate and methyl sulfide, with the concentration ranging from 13.25 to $18.06 \mu \mathrm{g} \mathrm{m}^{-3}$. Finally, 11 main hazardous air pollutant VOCs, accounting for $32.77 \%$ of the TVOCs, were propylene, 2-butanone, toluene, methyl methacrylate, etc., with the concentration ranging from 81.05 to $116.96 \mathrm{\mu g} \mathrm{m}^{-3}$. Results could contribute to filling the knowledge gaps in the characteristics of VOC emissions from biogas digestate (BD), and provide a basis for exploring mitigation strategies on odor and hazardous air pollutions.
\end{abstract}

Keywords: swine manure; digestate; VOCs; odorous; hazardous; air pollution

\section{Introduction}

Anaerobic digestion systems have been widely adopted as effective means of livestock manure treatment due to their advantages in being able to handle large amount of raw materials, simple process, high efficiency and generation of renewable energy [1]. However, a large amounts of biogas digestate resulting from biogas production is generally stored before its land application, making it an important source of pollutant gases [2-5]. The significance of emissions of greenhouse gases (i.e., methane $-\mathrm{CH}_{4}$ and nitrous oxide $\left.-\mathrm{N}_{2} \mathrm{O}\right)$, ammonia $\left(\mathrm{NH}_{3}\right)$ and hydrogen sulfide $\left(\mathrm{H}_{2} \mathrm{~S}\right)$ from livestock production has been well recognized and studied [6-12]. In comparison, research on volatile organic compounds (VOCs) released during biogas digestate storage has been meager.

VOCs are the main components of odorous substances in livestock manure management processes, and they cause a variety of undesirable reactions and even toxicity to people if the concentration exceeds a certain threshold $[13,14]$. VOCs are also important precursors of atmospheric photochemistry, 
some of which play a key role in the formation and production of atmospheric pollutants such as $\mathrm{O}_{3}$ and secondary organic aerosol [15-17]. However, most of the research about VOCs is focused on petrochemical, solvent and paint use, fuel combustion, waste treatment and other industries or fields [17-22]; and research on VOC emissions from animal husbandry mainly focused on building and manure compost [7-9,23-25]. Research on VOC emissions from liquid manure storage, especially biogas digestate storage, is almost non-existent.

Studies on ambient VOCs in livestock facilities demonstrated that oxygenated hydrocarbons are the dominant VOCs [8,23,26-29]. Trabue et al. [23] observed that the top five ambient VOC components (approximately 70\% of TVOCs) were acetic acid, 2,3-butanedione, methanol, acetone and ethanol on poultry farms. Blunden et al. [8] indicated that oxygenated hydrocarbons, i.e., ethanol, methanol, acetaldehyde and acetone, account for 37\% to $73 \%$ of the TVOCs observed in a pig house. Shaw et al. [26] reported that methanol, acetone, propylaldehyde and dimethyl sulfide are the dominant ambient VOC compositions for dairy. Hence, it seems that alcohols (i.e., methanol, ethanol, etc.), ketones (i.e., acetone, 2,3-butanedione, etc.) and aldehydes (i.e., acetaldehyde, etc.) are the common VOCs in the air of livestock and poultry farms.

While livestock waste and composting emissions are among the five largest emission sources of anthropogenic volatile organic compounds (VOCs) [30], studies about VOC emissions from manure management mainly focused on solid manure composting [24,25,31,32]. Eighty-one and 31 kinds of VOCs were determined by Zhou et al. [24] and Shen et al. [26], respectively, during pig manure composting. The sulfide compounds, i.e., dimethyl sulfide, dimethyl disulfide, dimethyl trisulfide, methyl sulfide, etc., were the dominant odorous VOCs in their studies. VOCs in biogas have also been investigated in some studies. Salazar Gómez et al. [2] observed that terpenes and ketones were the main VOCs in biogas from a farm-based biogas plant, and the amount varied from 35 to $1731 \mathrm{mg} \mathrm{m}^{-3}$. However, characteristics and concentrations of the VOCs emitted from stored biogas digestate remain unclear at the present time. This knowledge gap hampers the development of effective strategies for prevention and control of VOC pollution associated with the process of biogas digestate treatment and utilization.

Therefore, the objectives of this study were to characterize VOCs from biogas digestate storage, and to identify the VOC concentrations that pose potential odor and/or health impacts. The resultant data are expected to contribute to filling the gap of scientific knowledge and provide a scientific basis for mitigating VOC emissions from stored biogas digestate.

\section{Experiments}

\subsection{Biogas Digestate}

Fresh biogas digestate was collected from a local commercial swine farm biogas plant within $2 \mathrm{~h}$ driving distance and transported (in insulated containers) to Nankou Pilot Base of the Chinese Academy of Agricultural Sciences in Beijing, China. Homogenized through vibration/motion of the transport vehicle, the media were quickly pumped into the storage vessels (described below), where it was held for 5 days at a relatively constant temperature of $25^{\circ} \mathrm{C}$. The physical and chemical properties of the biogas digestate are listed in Table 1. During the experiment, the biogas digestate was in an acidic and anoxic state with a $\mathrm{pH}$ value of $5.40 \pm 0.38$ and dissolved oxygen (DO) concentration value lower than $0.3 \mathrm{mg} \mathrm{L}^{-1}$ (mean $\pm \mathrm{SD}: 0.021 \pm 0.006 \mathrm{mg} \mathrm{L}^{-1}$ ). While the laboratory room temperature was set at $25{ }^{\circ} \mathrm{C}$ during the experiment, the temperature of the biogas digestate $\left(21.70 \pm 1.38{ }^{\circ} \mathrm{C}\right)$ fluctuated with the temperature of the air pumped into the dynamic emission vessel (DEV). 
Table 1. Physicochemical properties of biogas digestate (mean (SD)).

\begin{tabular}{|c|c|c|c|c|c|}
\hline Property & Start & End & Property & Start & End \\
\hline $\begin{array}{l}\text { Chemical oxygen demand } \\
\left(\mathrm{COD}, \mathrm{mg} \mathrm{L}^{-1}\right)\end{array}$ & $\begin{array}{c}3816.67 \\
(2.71)\end{array}$ & $\begin{array}{l}3748.33 \\
(168.77)\end{array}$ & $\mathrm{pH}$ & $\begin{array}{c}5.91 \\
(0.05)\end{array}$ & $\begin{array}{c}5.02 \\
(0.01)\end{array}$ \\
\hline Total nitrogen $\left(\mathrm{TN}, \mathrm{mg} \mathrm{L}^{-1}\right)$ & $\begin{array}{l}1240.00 \\
(13.25)\end{array}$ & $\begin{array}{l}1313.33 \\
(16.78)\end{array}$ & Redox potential $(\mathrm{Rp}, \mathrm{mV})$ & $\begin{array}{l}102.90 \\
(3.08)\end{array}$ & $\begin{array}{l}154.21 \\
(0.91)\end{array}$ \\
\hline $\mathrm{NH}_{4}{ }^{+}-\mathrm{N}\left(\mathrm{mg} \mathrm{L}^{-1}\right)$ & $\begin{array}{l}896.00 \\
(61.64)\end{array}$ & $\begin{array}{l}808.00 \\
(45.63)\end{array}$ & $\begin{array}{l}\text { Electronic conductivity } \\
\quad\left(\mathrm{Ec}, \mathrm{ms} \mathrm{cm}^{-1}\right)\end{array}$ & $\begin{array}{c}9.79 \\
(0.53)\end{array}$ & $\begin{array}{l}11.86 \\
(0.58)\end{array}$ \\
\hline $\mathrm{NO}_{3}-\mathrm{N}\left(\mathrm{mg} \mathrm{L}^{-1}\right)$ & $\begin{array}{l}0.234 \\
(0.02)\end{array}$ & $\begin{array}{l}0.120 \\
(0.01)\end{array}$ & $\begin{array}{l}\text { Dissolved oxygen } \\
\left(\mathrm{DO}, \mathrm{mg} \mathrm{L}^{-1}\right)\end{array}$ & $\begin{array}{c}0.01 \\
(0.02)\end{array}$ & $\begin{array}{c}0.03 \\
(0.02) \\
\end{array}$ \\
\hline Total solid (TS, \%) & $\begin{array}{l}1.50 \\
(0.37)\end{array}$ & $\begin{array}{l}1.56 \\
(0.69)\end{array}$ & $\mathrm{T}\left({ }^{\circ} \mathrm{C}\right)$ & $\begin{array}{l}20.27 \\
(0.14)\end{array}$ & $\begin{array}{l}23.49 \\
(0.14)\end{array}$ \\
\hline Volatile solid (VS, \%) & $\begin{array}{c}0.89 \\
(0.22)\end{array}$ & $\begin{array}{c}0.90 \\
(0.43)\end{array}$ & $\begin{array}{l}\text { Total dissolved solid } \\
\text { (TDS, ppt) }\end{array}$ & $\begin{array}{c}4.80 \\
(0.26)\end{array}$ & $\begin{array}{c}5.81 \\
(0.28)\end{array}$ \\
\hline
\end{tabular}

\subsection{Experimental Set-Up and Methods}

Three Polymethyl methacrylate (PMMA) column-shaped DEVs were constructed and used in this study. The DEVs each had an inside diameter of $0.4 \mathrm{~m}$ and a height of $1.35 \mathrm{~m}$, consisting of the biogas digestate (BD) storage part and an air inlet/outlet system. As shown in Figure 1, the BD storage depth was $1.0 \mathrm{~m}$, and three sampling ports were added for BD sampling during the experiment, including one port on the lid through a guiding tube $(9.4 \mathrm{~cm}$ inside diameter $\times 40 \mathrm{~cm}$ length) partially inserted into the $\mathrm{BD}(5 \mathrm{~cm})$ for upper layer sampling and two ports at $5 \mathrm{~cm}$ and $50 \mathrm{~cm}$ above the base for the middle layer and bottom layer sampling, respectively. A headspace of $0.35 \mathrm{~m}$ height or about $40 \mathrm{~L}$ was used to accommodate the air inlet and outlet, both on the lid. During the experiment, fresh air was pumped into the DEV by a supply system that consisted of an air compressor, an air distribution system, and a set of mass flow meters/controllers. The flow rate was set at $6 \mathrm{~L} \mathrm{~min}^{-1}$ for each DEV. The PMMA and air handling tubing (Teflon tubes) were composed of methyl methacrylate and polytetrafluoroethylene, respectively, the chemical properties of which are stable, not interfering with the VOC results in this study.

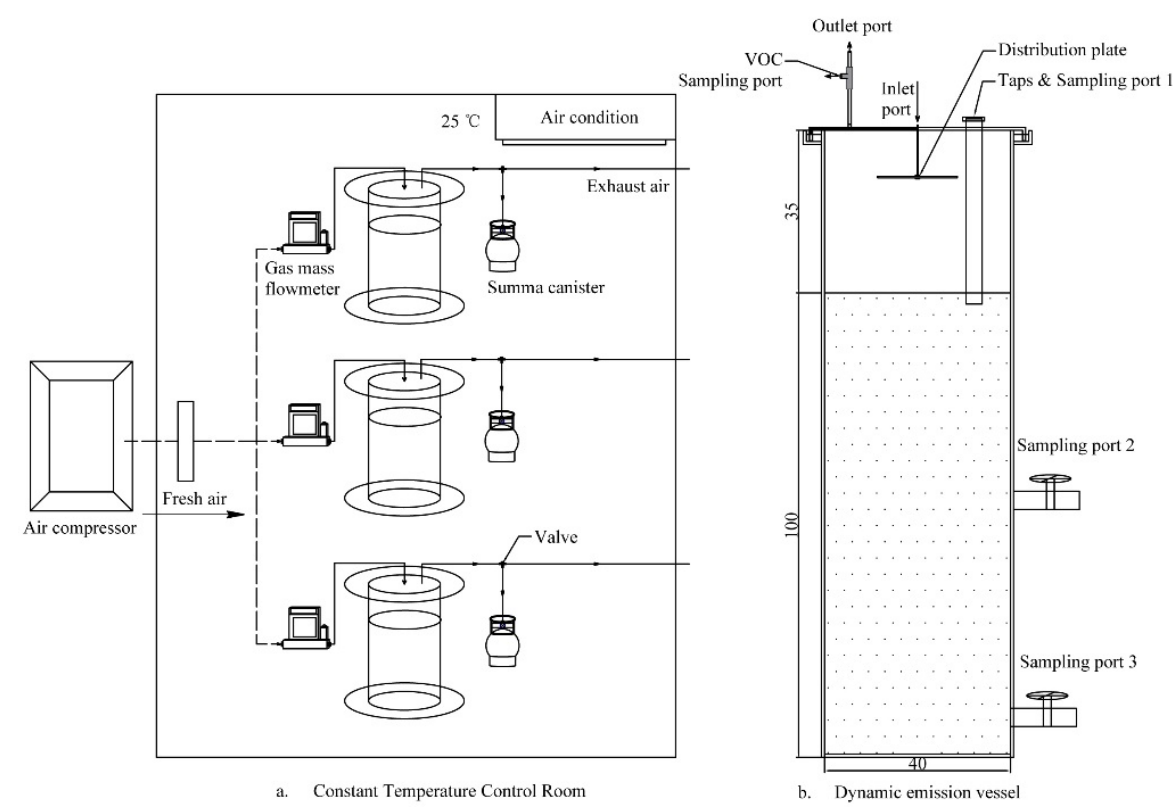

Figure 1. Schematic representation of the experimental setup (a) and dynamic emission vessel (b). 


\subsection{Sampling and Analysis}

\subsubsection{VOC Sampling and Analysis}

VOC air samples from each storage vessel were collected in fused silica lined (3.2 L, FSL) summa canisters (Entech Instruments Inc., Simi Valley, CA, USA) on the first, second, third and fifth day of the experiment. All canisters were cleaned three times with an Entech 3100A automated cleaner system (Entech Instrument, USA) and vacuumed to 1.33 Pa prior to sampling. The canister was connected to the DEV air outlet through a $50 \mathrm{~cm}$ Teflon tube. Sample collection lasted $5 \mathrm{~min}$, with the valve half-open for the first $2 \mathrm{~min}$ and fully open for the remaining $3 \mathrm{~min}$. A total of 12 samples were collected during the experiment. In addition, the concentrations of VOCs in fresh air were detected in the experiment in our group. The average concentration was $0.98 \pm 0.30 \mu \mathrm{g} \mathrm{m}^{-3}$, which was several orders of magnitude lower than that in this study. Therefore, the effect of VOCs in fresh air could be ignored.

The canister samples were taken to the Beijing Center for Physical \& Chemical Analysis located in Beijing, China, where they were analyzed using a canister sampling/concentration system (7500 Canister Autosampler, 7100 concentrator, Entech Instrument, Simi Valley, CA, USA) coupled to a 7890A GC (Agilent Technologies, Inc., Wilmington, DE, USA) with mass spectrometer (5975C Inert MSD, Agilent Technologies, Inc.). The 7100 used a three-stage concentration procedure that removed sampled water via the micropurge and trap technique prior to GC-MS analysis. The 7890A GC was equipped with DB-624 column $(60 \mathrm{~m} \times 0.25 \mathrm{~mm} \times 1.8 \mu \mathrm{m})$ (Agilent, USA) using helium gas at $1.0 \mathrm{~mL} \mathrm{~min}{ }^{-1}$ constant flow. The oven temperature program was as follows: Initial temp: $-10^{\circ} \mathrm{C}$, held for $10 \mathrm{~min}$; ramp $3{ }^{\circ} \mathrm{C} \mathrm{min}^{-1}$ to $100{ }^{\circ} \mathrm{C}$; ramp $10{ }^{\circ} \mathrm{C} \mathrm{min}{ }^{-1}$ to final temperature, $220{ }^{\circ} \mathrm{C}$; and held for $15 \mathrm{~min}$. Mass spectrometer was operating in scan mode with electron ionization. The scan was set from $\mathrm{m} / \mathrm{z}$ 29-280 amu in 5.4 scans s $^{-1}$.

Rigorous quality assurance and quality control procedures were followed throughout the study. VOC species were quantified using two standard gases purchased from Specialty Gases Inc., USA: US EPA PAMS and US EPA TO-14, and a total of 75 kinds of compositions were used in the analysis. The method detection limit (MDL) of the GC-MS ranged from 0.01 to $0.3 \mathrm{ppbv}$ for each target species with the gas injection of $400 \mathrm{~mL}$. Before samples testing, calibration had been made with standard gas to ensure accurate qualitative and quantitative analysis.

\subsubsection{Digestate Sample Collection and Analysis}

Two $450 \mathrm{~mL}$ representative BD samples were collected from each DEV on the first day and the last day of the storage period after stirring the media for homogeneity. During the storage period, three $150 \mathrm{~mL}$ samples were taken from the upper layer, middle layer and bottom layer of each DEV per day. Then, $450 \mathrm{~mL}$ of $4{ }^{\circ} \mathrm{C}$ preserved $\mathrm{BD}$ was added to each vessel via the guiding tube after sampling to maintain the digestate volume in the DEV. The instruments and analytical methods used to measure the physicochemical properties of BD are listed in Table 2. 
Table 2. Instruments and methods for analyzing the physicochemical properties of biogas digestate (BD).

\begin{tabular}{|c|c|c|}
\hline Property & Instruments/Methods & Instrument/Vendor Information \\
\hline $\mathrm{TN}$ & $\begin{array}{l}\text { Potassium persulphate method, method } 10071 \\
\text { (Test'N Tube TM tube) }\end{array}$ & DR 6000, HACH, US \\
\hline COD & $\begin{array}{l}\text { Reactor digestion method, method } 8000 \\
\text { (Test'N Tube TM tube) }\end{array}$ & DR 6000, HACH, US \\
\hline $\mathrm{NH}_{4}{ }^{+}-\mathrm{N}$ & $\begin{array}{l}\text { Salicylic acid method, method } 10031 \\
\text { (Test'N Tube TM tube) }\end{array}$ & DR 6000, HACH, US \\
\hline $\mathrm{NO}_{\mathrm{x}}{ }^{-}-\mathrm{N}$ & $\begin{array}{l}\text { N-(1-naphthyl)-ethylenediamine colorimetric } \\
\text { method (GB13580.7-92) }\end{array}$ & FIAstar 5000 Flow injection analyzer \\
\hline TS, VS & Constant weight test & $\begin{array}{c}\text { Oven (Japan YAMATO DN60), } \\
\text { Muffle furnace (China), One-thousandth } \\
\text { balance (Sartorius, Germany) }\end{array}$ \\
\hline $\mathrm{T}, \mathrm{DO}, \mathrm{pH}, \mathrm{Rp}, \mathrm{TDS}$ and Ec & $\begin{array}{l}\text { ORION STAR A329 PH/ISE/ Conductivity } \\
\text { /RDO/DO Portable multi-parameter } \\
\text { measuring instrument }\end{array}$ & Thermo Scientific, Singapore \\
\hline
\end{tabular}

\subsubsection{Determination of VOC Flux}

With the knowledge of VOC concentration, air flow rate of each DEV and physical dimensions of the DEV, emission flux of each VOC from the storage vessels was calculated using Equation (1):

$$
\mathrm{F}=\left(c_{1}-c_{0}\right) \times \mathrm{v} \times 10^{-3} / \mathrm{S}
$$

where $\mathrm{F}$ is the emission flux $\left(\mu \mathrm{g} \mathrm{m}^{-2} \mathrm{~min}^{-1}\right), \mathrm{c}_{1}$ and $\mathrm{c}_{0}$ represent the VOC concentration of outlet and inlet air, respectively $\left(\mu \mathrm{g} \mathrm{m}^{-3}\right), \mathrm{v}$ is the ventilation rate $\left(\mathrm{L} \mathrm{min}^{-1}\right), \mathrm{S}$ is the surface area of the stored $\mathrm{BD}\left(\mathrm{m}^{2}\right)$.

\subsection{Statistical Analysis}

Basic statistical analysis of the data was calculated using the stat. desc () function from pastecs package by $R$ (3.5.3). The values less than the first quartile (Q1) - 1.5 interquartile range (IQR) or greater than the third quartile $(\mathrm{Q} 3)+1.5 \mathrm{IQR}$ were defined as outliers and were treated as missing values by multiple interpolation method. The Spearman correlation between factors and its significance were calculated and detected by corr. test () function from psych package. Data plotting was done by ggplot2 package in R (3.5.3) and SigmaPlot 12.5.

\section{Results and Discussion}

\subsection{The Abundance of Main VOC Classes}

A total of 49 compounds of VOCs were detected during the biogas digestate storage, including 8 alkanes, 2 olefins, 14 halogenated hydrocarbons, 8 aromatic hydrocarbons, 11 OVOCs, 3 Freons and 3 sulfur compounds. The concentration ranges of VOCs observed in this study are shown in Figure 2. The amount of TVOC concentration during the five-day storage varied from 171.35 to $523.71 \mathrm{\mu g} \mathrm{m}^{-3}$, with an average value of $299.87 \pm 154.80 \mu \mathrm{g} \mathrm{m}^{-3}$. The emission flux of TVOCs ranged from 11.79 to $36.03 \mathrm{mg} \mathrm{day}^{-1} \mathrm{~m}^{-2}$, with an average value of $20.63 \pm 10.65 \mathrm{mg} \mathrm{day}^{-1} \mathrm{~m}^{-2}$. By the end of the experiment, the cumulative emission flux was up to $97.73 \mathrm{mg} \mathrm{m}^{-2}$. Compared with hog barn and other manure management systems, the concentration of TVOCs emitted from the stored BD was similar to that from pig house air $[8,9]$ but lower than that from pig manure composting and concentrations in biogas [2,33] (see Table 3). 


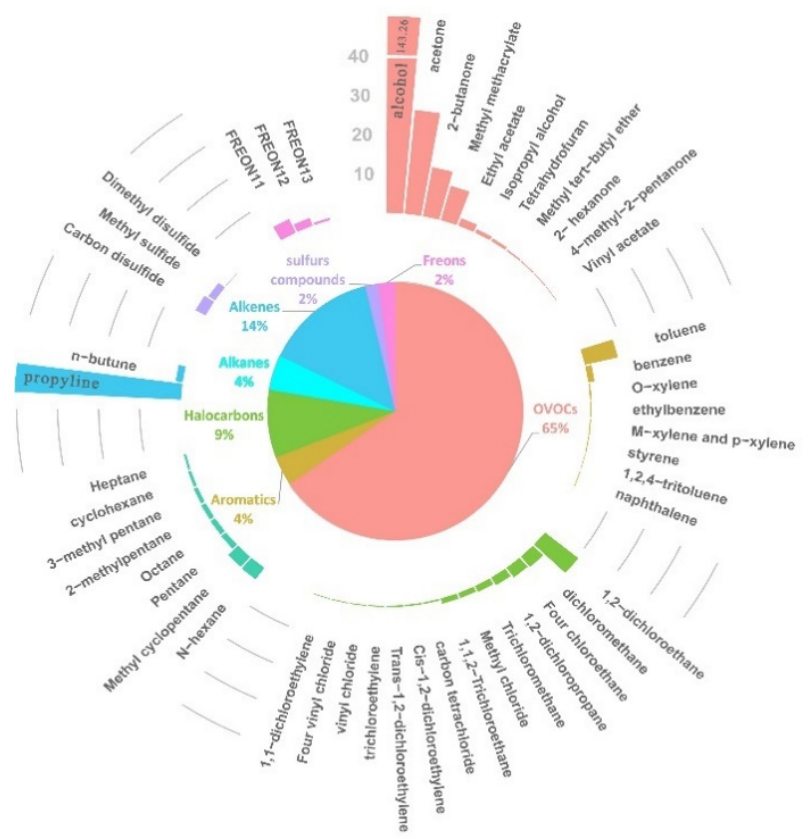

Figure 2. Species and concentrations of volatile organic compounds (VOCs) detected during the biogas digestate storage.

Table 3. VOC emissions of livestock production and manure management as reported in literature.

\begin{tabular}{|c|c|c|c|c|c|}
\hline Source & $\begin{array}{l}\text { Number } \\
\text { of VOCs }\end{array}$ & Methods & Main VOC Types & Concentration & Reference \\
\hline Barn & - & $\begin{array}{l}\text { Summa }{ }^{\mathrm{TM}} \text { canisters- } \\
\text { GC/FID system and } \\
\text { GC/MS }\end{array}$ & $\begin{array}{l}\text { Oxygenated hydrocarbons, } \\
\text { i.e., ethanol, methanol, } \\
\text { acetaldehyde, acetone }\end{array}$ & $\begin{array}{c}\text { B1: } 0.8-249.97 \mathrm{ppb} \\
\text { B2: 62.9-88.3 ppb } \\
\text { B3: 310.8-437.9 ppb } \\
\text { B4: } 124.6-368.6 \mathrm{ppb} \\
\text { B5: }-3.6-281.2 \mathrm{ppb}\end{array}$ & $\begin{array}{l}\text { Blunden et al. } \\
\text { [8] }\end{array}$ \\
\hline Compost & 81 & $\begin{array}{c}\text { Summa } \\
\text { canisters-GC/MS }\end{array}$ & Sulfur compounds, alkanes & - & Zhou et al. [24] \\
\hline \multirow{2}{*}{$\begin{array}{l}\text { Biogas } \\
\text { Plant }\end{array}$} & 15 & $\begin{array}{l}\text { Nalophan } \mathrm{NA}_{\mathrm{C}} \\
\text { bags-GC/MAS }\end{array}$ & Sulphur compounds & $5-8 \mathrm{mg} \mathrm{m}^{-3}$ & Rasi et al. [33] \\
\hline & & Sorbent tubes & Terpenes, ketones & 35-1731 mg Nm ${ }^{-3}$ & $\begin{array}{c}\text { Salazar } \\
\text { Gómez et al. [2] }\end{array}$ \\
\hline $\begin{array}{c}\text { Biogas } \\
\text { Digestate }\end{array}$ & 48 & $\begin{array}{c}\text { Summa } \\
\text { canisters-GC/MS }\end{array}$ & $\begin{array}{c}\text { OVOCs, alkenes, } \\
\text { halogenated hydrocarbon }\end{array}$ & $\begin{array}{c}171.35-523.71 \mu^{-3 ~ m^{-3}} \\
\left(61.36-231.71 \mathrm{ppbV}^{-}\right.\end{array}$ & $\begin{array}{l}\text { This study } \\
\text { (2019) }\end{array}$ \\
\hline
\end{tabular}

The results indicated that OVOCs, olefins and halogenated hydrocarbons were the dominant VOC classes from the stored BD. The concentration of OVOCs was $196.20 \pm 148.97 \mu \mathrm{g} \mathrm{m}^{-3}$, ranging from 85.28 to $410.11 \mu \mathrm{g} \mathrm{m}^{-3}$, and accounting for $65.43 \%$ of the TVOCs. Olefins and halogenated hydrocarbons accounted for $14.12 \%$ and $8.53 \%$ of the TVOCs, respectively, and their concentration averaged, respectively, $42.35 \pm 8.50 \mu \mathrm{g} \mathrm{m}^{-3}$ (range of $30.17 \sim 48.48 \mu \mathrm{g} \mathrm{m}^{-3}$ ) and $25.58 \pm 4.85 \mu \mathrm{g} \mathrm{m}^{-3}$ (range of 20.78 31.14 $\mathrm{\mu g} \mathrm{m}^{-3}$ ). Turan et al. [31], Shaw et al. [26] and Blunden et al. [8] indicated that the main VOCs in a livestock farming environment were composed of oxygenated compounds, which was 
consistent with the results of this study. This study investigated VOC emissions from the same batch of biogas digestate, and the same volume of preserved digestate was added after sampling. However, in the actual storage process, fresh biogas digestate may be added to the storage frequently, which may cause higher VOCs emission due to the disturbing and fresh components.

\subsection{Main Compositions of VOCs}

The 49 compounds of VOCs detected in this experiment included 22 of the hazardous air pollutants listed by the US Environmental Protection Agency (USEPA), 6 of the odorous pollutants controlled by the Japanese Environmental Protection Agency, and 4 of the 8 odorous pollutants controlled by the Chinese odorous pollutant discharge standards (GB14554-93). Table 4 lists the top 20 compositions of VOCs released from the biogas digestate in this study. The average total VOC concentration of the top 20, represented by TVOCs ${ }_{\text {Top } 20}$, was $284.06 \pm 154.15 \mu \mathrm{g} \mathrm{m}^{-3}$, accounting for $94.73 \%$ of the TVOCs. In this study, the highest concentration of VOC species was ethanol, accounting for $47.78 \%$ of the TVOCs.

Table 4. Top 20 most abundant VOC species $\left(\mu \mathrm{g} \mathrm{m}^{-3}\right)$ measured in this study.

\begin{tabular}{cccc}
\hline VOC Compositions & Concentration Mean (SD) & VOCs Compositions & Concentration Mean (SD) \\
\hline Ethanol & $143.26(150.37)$ & $n$-Hexane & $3.38(1.36)$ \\
Propylene & $40.66(8.42)$ & 1,2-Dichloropropane & $3.00(0.86)$ \\
Acetone & $26.50(3.19)$ & Methyl cyclopentane & $2.80(2.07)$ \\
2-Butanone & $12.64(2.81)$ & Ethyl acetate & $2.27(0.79)$ \\
1,2-Dichloroethane & $10.47(1.66)$ & $1,1,2$-Trichloroethane & $2.08(0.81)$ \\
Toluene & $9.05(2.20)$ & FREON12 & $2.01(0.05)$ \\
Methyl methacrylate & $8.24(3.30)$ & Methyl sulfide & $1.90(0.35)$ \\
FREON11 & $3.85(2.55)$ & Four chloroethane & $1.69(0.21)$ \\
Dichloromethane & $3.60(1.65)$ & $n$-Butune & $1.66(0.68)$ \\
Carbon disulfide & $3.46(2.29)$ & Trichloromethane & $1.53(0.40)$ \\
\hline
\end{tabular}

The next predominant VOCs were propylene, acetone and 2-butanone, accounting for $13.56 \%$, $8.84 \%$ and $4.21 \%$ of the TVOCs, respectively. Rumsey et al. [34] detected a large amount of ethanol and acetone in VOCs emitted from pig manure anaerobic lagoon, which paralleled the results of the current study. However, Rasi et al. [33] demonstrated that the main components of VOCs in farm biogas were sulfur compounds, suggesting that there may be differences in the VOCs released between the anaerobic fermentation process and its subsequent storage process. Thus, manure management systems may be the driving forces for different dominant VOC compositions released from livestock manure systems.

\subsection{Odorous VOCs}

Malodorous pollutants refer to the gaseous substances that stimulate olfactory organs, causing people unhappiness and degrading the living environment. VOCs are the main components of malodorous pollutants in a livestock environment [9]. In this study, toluene, carbon disulfide, ethyl acetate and methyl sulfide, were the dominant odorous substances in the total concentration ranging from 13.25 to $18.06 \mu \mathrm{g} \mathrm{m}^{-3}\left(15.45 \pm 2.02 \mu \mathrm{g} \mathrm{m}^{-3}\right)$, which accounted for $5.15 \%$ of the TVOCs. While dimethyl disulfide and styrene were also detected, their concentrations were only $0.15 \pm 0.03 \mu \mathrm{g} \mathrm{m}^{-3}$ and $0.14 \pm 0.02 \mu \mathrm{g} \mathrm{m}^{-3}$. The changes of the concentration and emission flux during the digestate storage are shown in Figure 3. The concentrations of methyl sulfide and ethyl acetate decreased by $26.29 \%$ and $38.40 \%$, respectively. The concentration of toluene tended to be stable during the storage, while the concentration of carbon disulfide increased by $27.25 \%$ on the fifth day. The results of flux statistics show that the cumulative emissions of toluene, carbon disulfide, ethyl acetate and methyl sulfide during storage were $3.03 \mathrm{mg} \mathrm{m}^{-2}, 0.88 \mathrm{mg} \mathrm{m}^{-2}, 0.68 \mathrm{mg} \mathrm{m}^{-2}$ and $0.62 \mathrm{mg} \mathrm{m}^{-2}$, respectively. It is noteworthy that, although odorous pollutants consisting mainly of toluene, carbon 
disulfide, ethyl acetate and methyl sulfide were observed in this study, their concentrations were lower than the olfactory threshold [35]. The relatively low VOC concentrations in this study may have stemmed from the static state with less disturbance in the BD storage.

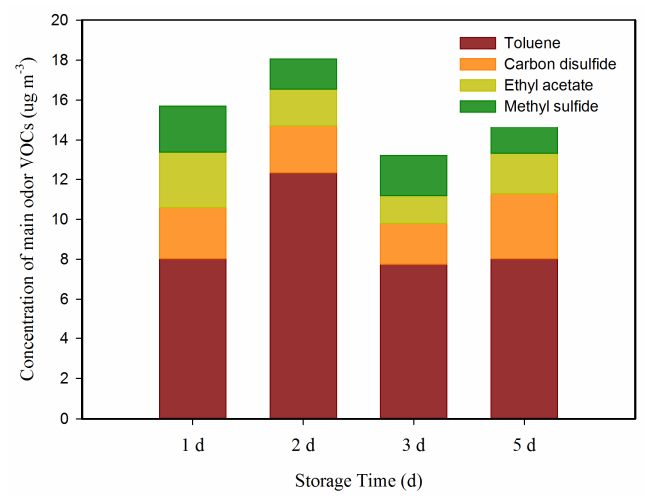

(a)

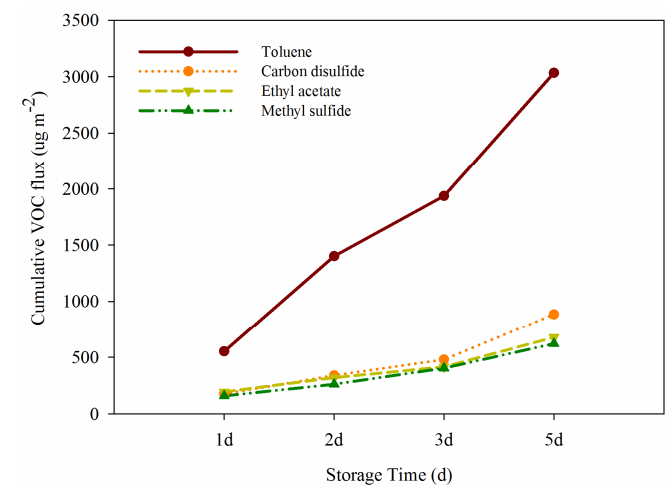

(b)

Figure 3. (a) Concentrations of main odorous VOCs during the biogas digestate (BD) storage; (b) cumulative fluxes of main odorous VOCs during the BDs.

Seventy-one odorous VOCs were detected at the manure treatment plant, and toluene, dimethyl disulphide, dimethy sulphide, xylene and ethylbenzene were the five most abundant pollutions in Li's study [36]. Zhou et al. [24] observed that the main odor VOCs in the manure composting process were trimethylamine, dimethyl sulfide (methyl sulfide), dimethyl disulfide and dimethyl trisulfide. Anna [7] indicated that the main components of VOCs in a pig farm were hexanal and sulfur compounds (i.e., methyl mercaptan, isopropyl mercaptan and carbon disulfide), which was similar to the results of this study. Despite differences in the specific categories, sulfur compounds seem to be the main and ubiquitous odorous substances in pig manure management.

\subsection{Hazardous VOCs}

The VOCs observed in the stored BD of this study include 22 hazardous air pollutants listed by the US Environmental Protection Agency (USEPA), and 11 of these had relatively high concentrations (Figure 4), including propylene, 2-butanone, toluene, methyl methacrylate, carbon disulfide, n-hexane and chlorinated paraffin (1,2-dichloroethane, dichloromethane, 1,2,1-dichloro propane, 1,2-trichloroethane, tetrachloroethane), which accounted for $32.77 \%$ of the TVOCs. The total concentration of the main hazardous VOCs ranged from 81.05 to $116.96 \mu \mathrm{g} \mathrm{m}^{-3}$, with an average value of $98.27 \pm 16.28 \mu \mathrm{g} \mathrm{m}^{-3}$. The cumulative emission flux of hazardous VOCs during the five-day BD storage was $32.89 \mathrm{mg} \mathrm{m}^{-2}$. The previous study found that compositions such as benzene, toluene, $m$-p-xylene, $o$-xylene and acetone had significant effects on asthma symptoms in children [1], and the high concentration of toluene and acetone were observed in this study. However, at present we lack a robust, standardized approach to rank the potential harm caused by different VOCs, which prevents effective action to improve indoor air quality and reduce impacts on human health [37]. The EPA's Integrated Risk Information System (IRIS) has been working to identify and characterize the health hazards of chemicals; the toxicity value of the hazardous VOCs detected in this study are listed in Table S1 based on the data from IRIS (EPA) (https://cfpub.epa.gov/ncea/iris/search/index.cfm) [38]. Of the 22 hazardous VOCs detected in this study, 8 were identified to be or likely to be carcinogenic, and 14 were identified to be harmful to other human organs or systems, such as the nervous system, olfactory epithelium and so on (Tables S1 and S2). 


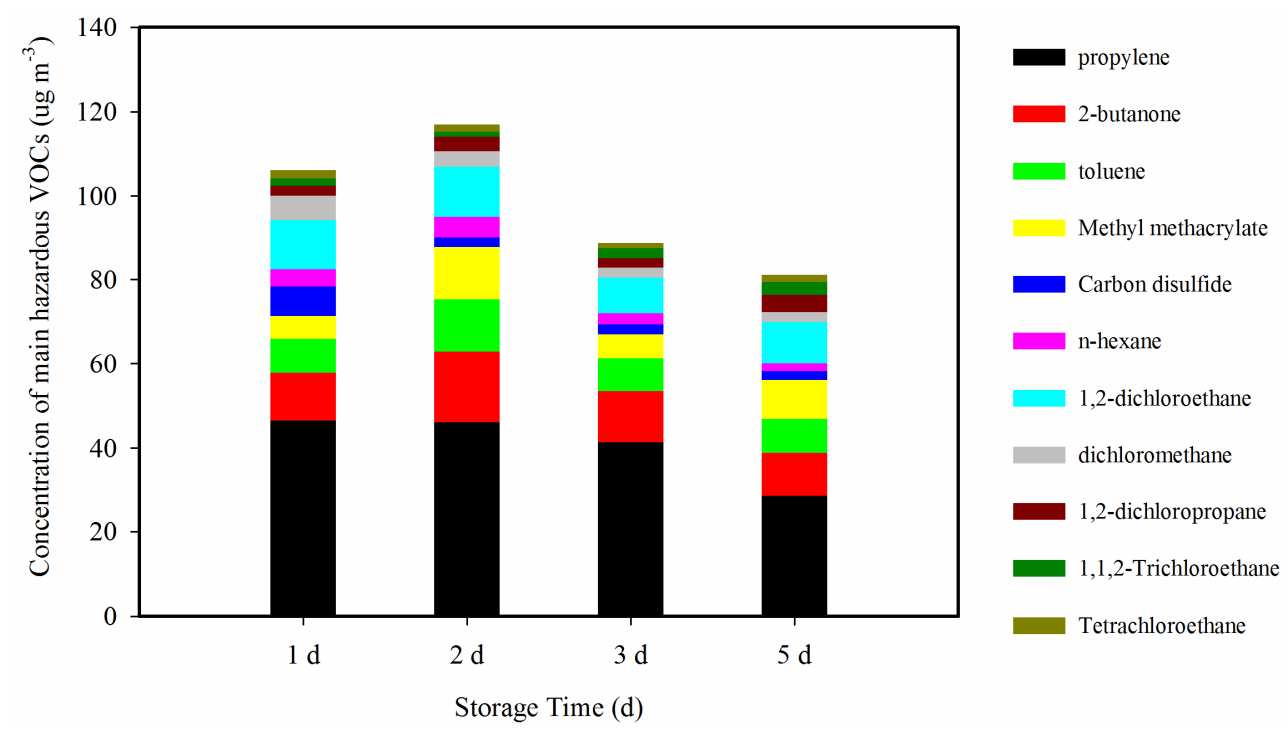

Figure 4. Changes in contents of main hazardous VOCs during five-day storage of biogas digestate.

Studies on VOCs associated with livestock farming and manure management have mostly focused on odorous pollutants. In this study, the proportion of hazardous air pollutants (32.77\%) was shown to be considerably higher than that of odorous pollutants (5.15\%). Hence, more attention should also be paid to emissions of hazardous air pollutants during biogas digestate storage processes.

\section{Conclusions}

Characteristics of VOCs emitting from biogas digestate during five-day storage at $21.7 \pm 1.4{ }^{\circ} \mathrm{C}$ were analyzed. The following conclusions were drawn:

- A total of 49 compositions were identified, including 8 alkanes, 2 olefins, 14 halogenated hydrocarbons, 8 aromatic hydrocarbons, 11 OVOCs, 3 freons and 3 sulfur compounds. Many of the identified VOCs are classified as odorous or hazardous air pollutants.

- OVOCs, olefins and halogenated hydrocarbons dominated the compositions, accounting for $65.43 \%, 14.12 \%$ and $8.53 \%$ of the TVOCs, respectively.

- Ethanol, propylene, acetone and 2-butanone were the top four concentrated VOCs.

- Toluene, carbon disulfide, ethyl acetate and methyl sulfide were the dominant odorous substances, accounting for $5.15 \%$ of the TVOCs.

- Hazardous VOCs emitting from biogas digestate storage deserve more attention, especially from the standpoint of the potential impact on the atmospheric environment.

Supplementary Materials: The following are available online at http://www.mdpi.com/2073-4433/10/7/411/s1, Table S1: Toxicity Value of hazardous VOCs from biogas digestate storage, Table S2. The calibration equation, RSD, R2 and method detection limits (MDL) of GC-MS for top 20 most abundant VOC species detected in this study.

Author Contributions: Conceptualization, Y.Z. (Yu Zhang), Y.Z. (Yunhao Zheng), Y.C. and H.D.; Formal Analysis, Y.Z. (Yu Zhang) and Y.Z. (Yunhao Zheng); Funding Acquisition, H.D.; Investigation, Y.Z. (Yu Zhang); Methodology, Z.Z., F.Y., W.Z. and H.D.; Project Administration, H.D.; Resources, Z.Z., Y.Z. (Yunhao Zheng), Y.C., F.Y. and W.Z.; Supervision, H.D.; Writing-Original Draft, Y.Z. (Yu Zhang); Writing—Review and Editing, Y.Z. (Yunhao Zheng), H.D. and H.X.

Funding: This research was funded by the China Agriculture Research System, grant number CARS-35-10B and the National Research Program for Key Issues in Air Pollution Control, grant number DQGG0208-03.

Acknowledgments: We thank all our colleagues for their recommendations and support during this study. Funding for the study was provided by the China Agriculture Research System (CARS-35-10B) and the National Research Program for Key Issues in Air Pollution Control (DQGG0208-03).

Conflicts of Interest: The authors declare no conflict of interest. 


\section{References}

1. Delfino, R.J.; Gong, H., Jr.; Linn, W.S.; Pellizzari, E.D.; Hu, Y. Asthma symptoms in Hispanic children and daily ambient exposures to toxic and criteria air pollutants. Environ. Health Perspect. 2003, 111, 647-656. [CrossRef] [PubMed]

2. Salazar Gómez, J.I.; Lohmann, H.; Krassowski, J. Determination of volatile organic compounds from biowaste and co-fermentation biogas plants by single-sorbent adsorption. Chemosphere 2016, 153, 48-57. [CrossRef] [PubMed]

3. Wang, Y.; Feng, L.; Zhao, X.; Ma, X.; Yang, J.; Liu, H.; Dou, S.; Zhou, M.; Xie, Z. Characteristics of volatile compounds removal in biogas slurry of pig manure by ozone oxidation and organic solvents extraction. J. Environ. Sci. 2013, 25, 1800. [CrossRef]

4. Akhiar, A.; Battimelli, A.; Torrijos, M.; Carrere, H. Comprehensive characterization of the liquid fraction of digestates from full-scale anaerobic co-digestion. Waste Manag. 2017, 59, 118-128. [CrossRef] [PubMed]

5. Giannadaki, D.; Giannakis, E.; Pozzer, A.; Lelieveld, J. Estimating health and economic benefits of reductions in air pollution from agriculture. Sci. Total Environ. 2018, 622-623, 1304-1316. [CrossRef]

6. Wang, Y.; Li, X.; Yang, J.; Tian, Z.; Sun, Q.; Xue, W.; Dong, H. Mitigating Greenhouse Gas and Ammonia Emissions from Beef Cattle Feedlot Production: A System Meta-Analysis. Environ. Sci. Technol. 2018, 52, 11232-11242. [CrossRef]

7. Anna, C. The concentration of volatile organic compounds (VOCs) in pig farm air. Ann. Agric. Environ. Med. 2009, 16, 249-256.

8. Blunden, J.; Aneja, V.P.; Lonneman, W.A. Characterization of non-methane volatile organic compounds at swine facilities in eastern North Carolina. Atmos. Environ. 2005, 39, 6707-6718. [CrossRef]

9. Cai, L.; Koziel, J.A.; Lo, Y.C.; Hoff, S.J. Characterization of volatile organic compounds and odorants associated with swine barn particulate matter using solid-phase microextraction and gas chromatography-mass spectrometry-olfactometry. J. Chromatogr. A 2006, 1102, 60-72. [CrossRef]

10. Filipy, J.; Rumburg, B.; Mount, G.; Westberg, H.; Lamb, B. Identification and quantification of volatile organic compounds from a dairy. Atmos. Environ. 2006, 40, 1480-1494. [CrossRef]

11. Wang, Y.; Dong, H.; Zhu, Z.; Gerber, P.J.; Xin, H.; Smith, P.; Opio, C.; Steinfeld, H.; Chadwick, D. Mitigating Greenhouse Gas and Ammonia Emissions from Swine Manure Management: A System Analysis. Environ. Sci. Technol. 2017, 51, 4503-4511. [CrossRef] [PubMed]

12. Cunha, C.S.; Lopes, N.L.; Veloso, C.M.; Jacovine, L.A.; Tomich, T.R.; Pereira, L.G.; Marcondes, M.I. Greenhouse gases inventory and carbon balance of two dairy systems obtained from two methane-estimation methods. Sci. Total Environ. 2016, 571, 744-754. [CrossRef] [PubMed]

13. Nicell, J.A. Assessment and regulation of odour impacts. Atmos. Environ. 2009, 43, 196-206. [CrossRef]

14. Orzi, V.; Riva, C.; Scaglia, B.; D'Imporzano, G.; Tambone, F.; Adani, F. Anaerobic digestion coupled with digestate injection reduced odour emissions from soil during manure distribution. Sci. Total Environ. 2018, 621, 168-176. [CrossRef] [PubMed]

15. Toro, M.V.; Cremades, L.V.; Calbo, J. Relationship between VOC and NOx emissions and chemical production of tropospheric ozone in the Aburra Valley (Colombia). Chemosphere 2006, 65, 881-888. [CrossRef]

16. Ziemann, P.J.; Atkinson, R. Kinetics, products, and mechanisms of secondary organic aerosol formation. Chem. Soc. Rev. 2012, 41, 6582-6605. [CrossRef]

17. Zheng, J.Y.; Shao, M.; Che, W.W.; Zhang, L.J.; Zhong, L.J.; Zhang, Y.H.; Streets, D. Speciated VOC emission inventory and spatial patterns of ozone formation potential in the Pearl River Delta, China. Environ. Sci. Technol. 2009, 43, 8580-8586. [CrossRef]

18. Klimont, Z.; Streets, D.G.; Gupta, S.; Cofala, J.; Fu, L.; Ichikawa, Y. Anthropogenic emissions of non-methane volatile organic compounds in China. Atmos. Environ. 2002, 36, 1309-1322. [CrossRef]

19. Wei, W.; Wang, S.; Chatani, S.; Klimont, Z.; Cofala, J.; Hao, J. Emission and speciation of non-methane volatile organic compounds from anthropogenic sources in China. Atmos. Environ. 2008, 42, 4976-4988. [CrossRef]

20. Guo, H.; Ling, Z.H.; Cheng, H.R.; Simpson, I.J.; Lyu, X.P.; Wang, X.M.; Shao, M.; Lu, H.X.; Ayoko, G.; Zhang, Y.L.; et al. Tropospheric volatile organic compounds in China. Sci. Total Environ. 2017, 574, 1021-1043. [CrossRef] 
21. Li, J.; Zhai, C.; Yu, J.; Liu, R.; Li, Y.; Zeng, L.; Xie, S. Spatiotemporal variations of ambient volatile organic compounds and their sources in Chongqing, a mountainous megacity in China. Sci. Total Environ. 2018, 627, 1442-1452. [CrossRef] [PubMed]

22. Wu, F.; Yu, Y.; Sun, J.; Zhang, J.; Wang, J.; Tang, G.; Wang, Y. Characteristics, source apportionment and reactivity of ambient volatile organic compounds at Dinghu Mountain in Guangdong Province, China. Sci. Total Environ. 2016, 548-549, 347-359. [CrossRef] [PubMed]

23. Trabue, S.; Scoggin, K.; Li, H.; Burns, R.; Xin, H.; Hatfield, J. Speciation of volatile organic compounds from poultry production. Atmos. Environ. 2010, 44, 3538-3546. [CrossRef]

24. Zhou, T.; Shang, B.; Dong, H.; Tao, X.; Liu, T.; Wang, Y. Emission characteristics of volatile organic compounds during pilot swine manure composting. Trans. Chin. Soc. Agric. Eng. 2017, 33, 192-198.

25. Shen, Y.; Zhang, B.; Zhao, L.; Meng, H.; Cheng, H. Component analysis of volatile organic compounds and determination of key odor in pig manure aerobic fermentation process. Trans. Chin. Soc. Agric. Eng. 2016, 32, 205-210.

26. Shaw, S.L.; Mitloehner, F.M.; Jackson, W.; DePeters, E.J.; Fadel, J.G.; Robinson, P.H.; Holzinger, R.; Goldstein, A.H. Volatile Organic Compound Emissions from Dairy Cows and Their Waste as Measured by Proton-Transfer-Reaction Mass Spectrometry. Environ. Sci. Technol. 2007, 41, 1310-1316. [CrossRef] [PubMed]

27. Ni, J.Q.; Robarge, W.P.; Xiao, C.; Heber, A.J. Volatile organic compounds at swine facilities: A critical review. Chemosphere 2012, 89, 769-788. [CrossRef] [PubMed]

28. Hobbs, P.J.; Webb, J.; Mottram, T.T.; Grant, B.; Misselbrook, T.M. Emissions of volatile organic compounds originating from UK livestock agriculture. J. Sci. Food Agric. 2004, 84, 1414-1420. [CrossRef]

29. Ngwabie, N.M.; Schade, G.W.; Custer, T.G.; Linke, S.; Hinz, T. Abundances and Flux Estimates of Volatile Organic Compounds from a Dairy Cowshed in Germany. J. Environ. Qual. 2008, 37, 565-573. [CrossRef]

30. Chen, J.; Luo, D. Ozone formation potentials of organic compounds from different emission sources in the South Coast Air Basin of California. Atmos. Environ. 2012, 55, 448-455. [CrossRef]

31. Turan, N.G.; Akdemir, A.; Ergun, O.N. Emission of Volatile Organic Compounds during Composting of Poultry Litter. Water Air Soil Pollut. 2007, 184, 177-182. [CrossRef]

32. Ryu, H.W.; Cho, K.S.; Lee, T.H. Reduction of ammonia and volatile organic compounds from food waste-composting facilities using a novel anti-clogging biofilter system. Bioresour. Technol. 2011, 102, 4654-4660. [CrossRef]

33. Rasi, S.; Veijanen, A.; Rintala, J. Trace compounds of biogas from different biogas production plants. Energy 2007, 32, 1375-1380. [CrossRef]

34. Rumsey, I.C.; Aneja, V.P.; Lonneman, W.A. Characterizing non-methane volatile organic compounds emissions from a swine concentrated animal feeding operation. Atmos. Environ. 2012, 47, 348-357. [CrossRef]

35. Pang, X.; Guo, X.; Qin, Z.; Yao, Y.; Hu, X.; Wu, J. Identification of aroma-active compounds in Jiashi muskmelon juice by GC-O-MS and OAV calculation. J. Agric. Food Chem. 2012, 60, 4179-4185. [CrossRef] [PubMed]

36. Li, J.J.; Wu, Y.D.; Zhang, Y.L.; Zeng, P.Y.; Tu, X.; Xu, M.Y.; Sun, G.P. Emission of odorous volatile organic compounds from a municipal manure treatment plant and their removal using a biotrickling filter. Environ. Technol. 2015, 36, 1050-1056. [CrossRef] [PubMed]

37. Carslaw, N.; Shaw, D. Secondary product creation potential (SPCP): A metric for assessing the potential impact of indoor air pollution on human health. Environ. Sci. Process. Impacts 2019. [CrossRef] [PubMed]

38. United States Environmental Protection Agency (EPA). Available online: https://cfpub.epa.gov/ncea/iris/ search/index.cfm (accessed on 5 July 2019).

(C) 2019 by the authors. Licensee MDPI, Basel, Switzerland. This article is an open access article distributed under the terms and conditions of the Creative Commons Attribution (CC BY) license (http://creativecommons.org/licenses/by/4.0/). 